\title{
Management of Outdoor Learning Models for Environmental Education Courses
}

\author{
Andika Adinanda Siswoyo ${ }^{1,}$, Agung Setyawan ${ }^{1}$, Tyasmiarni Citrawati ${ }^{1}$, Rita Prima Bendriyanti ${ }^{2}$, \\ Citra Dewi ${ }^{2}$ \\ ${ }^{1}$ Faculty of Education, Universitas Trunojoyo Madura, Indonesia \\ ${ }^{2}$ Faculty of Teacher Training and Education, Universitas Dehasen Bengkulu, Bengkulu, Indonesia
}

Received May 22, 2020; Revised August 24, 2020; Accepted September 11, 2020

\begin{abstract}
Cite This Paper in the following Citation Styles
(a): [1] Andika Adinanda Siswoyo, Agung Setyawan, Tyasmiarni Citrawati, Rita Prima Bendriyanti, Citra Dewi , "Management of Outdoor Learning Models for Environmental Education Courses," Universal Journal of Educational Research, Vol. 8, No. 11, pp. 5036-5043, 2020. DOI: 10.13189/ujer.2020.081103.
\end{abstract}

(b): Andika Adinanda Siswoyo, Agung Setyawan, Tyasmiarni Citrawati, Rita Prima Bendriyanti, Citra Dewi (2020). Management of Outdoor Learning Models for Environmental Education Courses. Universal Journal of Educational Research, 8(11), 5036-5043. DOI: 10.13189/ujer.2020.081103.

Copyright $\bigcirc 2020$ by authors, all rights reserved. Authors agree that this article remains permanently open access under the terms of the Creative Commons Attribution License 4.0 International License

\begin{abstract}
The purpose of this study is to describe the management of outdoor learning models in environmental education courses. The method used is descriptive qualitative, in which the researcher analyzes the results of the interview management model of outdoor learning based on the needs of the course. This activity takes place from December 2019 to February 2020. The sample of this study was 5 lecturers ( 3 women and 2 men) in the age range of 32-40 years. The sample selection technique was carried out intentionally by evaluating the teaching experience of environmental education courses for a minimum of 4 years. The results of this study were obtained from the management of outdoor learning models in environmental education courses divided into 5 stages, namely analyzing curriculum structure, study the potential and needs of courses, planning, implementation, and evaluation. The conclusion from this study is that outdoor learning models have various positive impacts on their application. The outdoor learning model will be implemented well if it is accompanied by good management. 5 stages in the management of the outdoor learning model are connected. Hope can be applied to other subjects. A finding in this study is outdoor learning models still require face-to-face class, but more time for activities outside the classroom. Activities in the class are in the form of initial coordination, delivery of product designs, and delivery of results. The management of the outdoor learning model needs to be tried in other subjects.
\end{abstract}

Keywords Management, Outdoor Learning Models, Environmental Education Courses

\section{Introduction}

The learning model is a whole set of teaching materials starting pre-activity until after the learning activity is carried out which involves all aspects of related facilities that are used either slenderly or indirectly. The learning model includes patterns used in curriculum preparation, arranging material to be used in learning, and giving instructions to teachers in class in the form of learning settings and others (Neill, Marsh, \& Richards, 2003). The outdoor learning model does not merely move the lesson outside the classroom but is done by inviting students to unite with nature and to do some activities that lead to the realization of changes in student behavior towards the environment through stages of awareness, understanding, attention, responsibility and action or behavior. Activities outside the classroom can be in the form of games, stories, sports, experiments, competitions, getting to know environmental cases and discussion (Rickinson 2004)

The learning process can occur anywhere, inside or outside the classroom, even outside of school. The learning process that is carried out outside the classroom or outside of school, has a very important meaning for student 
development because such a learning process can provide direct experience to students (Eriksson-Dobrovich, 2007). Direct experience allows the subject matter to be more concrete and real which means the learning process will be more meaningful. Ministry of Education (MOE, 2007) suggests that learning by using the environment enables students to find very meaningful relationships between abstract ideas and practical applications in real-world contexts, concepts understood through processes of discovery, empowerment, and relationships. Science learning can be done outside the classroom (outdoor education) by utilizing the environment as a natural laboratory. Learning outside the classroom (outdoor learning) can bring together various fields or subjects that make it possible for students to understand nature as a whole and intact, namely by making 'connections' between these fields (Setyawan, Aznam, Paidi\& Citrawati, 2020). Through experience outside the classroom, students will engage in activities through various seasons and in various weather conditions, so that it encourages adaptation and endurance. In addition, learning experiences like this also offer many opportunities for personal development and learning skills in various fields such as communication, problem-solving, information technology, working with others, creativity and thinking ability (Johnson \& Ivie, 2003). These competencies are needed by students to meet opportunities and challenges when the world changes rapidly.

Through the process of outdoor learning, a person builds a lot of his understanding of nature as a whole. Outdoor learning is not just an effort to find the right answer, but rather an effort to find a way to solve the right problem (Cuvo, May \& Post, 2001; Magnusson, 2006). For teachers, outdoor learning is more emphasis on developing skills and the maturation of attitudes or habits of thought that will be passed on to real life. Teaching material is very important, but as the ultimate goal of learning is not an understanding of the teaching material itself because knowledge about teaching material continues to grow and change. While no one can learn everything, everyone can develop the skills and maturity of attitudes needed to continue his life (Brodin \& Lindstrand, 2006; Westberg, 2007).

In modern education, learning skills and abilities are the most important learning goals or outputs. The natural environment is very important for the development process of children related to intelligence, creativity, problem-solving, emotional, social, spiritual, and physical (Morris \& Zidenberg-Cherr, 2002). Outdoor learning that takes place in the schoolyard can support creativity, problem-solving abilities, and stimulate children to be more cooperative. The habit of the eyes to observe and see outside the environment can improve students' cognitive abilities (Brodin, 2009). Research in the United States shows that schools that often use outdoor classrooms and nature-based experiential education significantly support the improvement of learning outcomes in various fields such as social, science, art, language, and mathematics. Even science test scores for students involved in outdoor learning programs have been shown to increase by $27 \%$ (American Institutes for Research, 2005). Contact with nature can significantly reduce symptoms of attention deficit disorder for five-year-olds (Kuo and Taylor, 2004). Children who regularly participate in learning programs with natural settings become more physically active, care more about health, have more tolerance for others, and are more creative and prefer to consume fruits and vegetables. (Dyment and Bell, 2008). Also, activities outside the classroom can show a better impact on students (Baker, Waliczek, \& Zajicek, 2015). Outdoor learning has a positive impact on school students. Learning outside the classroom creates new opportunities and challenges for students (Doctoroff, 2001; Spencer, 2003; Dahlgren \& Szczepanski, 2005), developing body and mind and emotions through new experiences, widening students' awareness and abilities, a new way to learn through the whole body of students, and achieve a balance between all parts of the outside environment.

The Outdoor learning model empowers students in obtaining information through outside learning and accustoms students to be able to overcome problems (Holman, McAvoy, Rynders, \& Goldenbe, 2003; Todd \& Reid, 2006). Appropriate management is needed in applying the outdoor learning model. Readiness and understanding of outdoor learning are very necessary because the process of activities is very complex and interconnected at each stage. Researchers try to describe the form of the management of outdoor learning models. On the subject of environmental education, the need to explore the management of the outdoor learning model is expected to provide benefits to develop the potential of students and utilize the availability of resources effectively and efficiently. In addition, the results of this study can be used as a guide for readers who want to apply the same model in other subjects.

\section{Methods}

\subsection{Design}

The method used is descriptive qualitative in which the researcher analyzes the results of the outdoor management interview model according to the needs of the course. The interview was conducted after the researchers received permission from the study program coordinator, the initial study process of observation and initial data collection as well as theories that support the preparation of interview instruments. Furthermore, the instrument was validated by experts in this case the researchers used 3 learning model experts input from experts related to the instrument becomes a study material for instrument improvement. After the instrument revision process, the researcher 
collects data and information in the field. Furthermore, researchers process the data to be described qualitatively to make conclusions based on the theory and the data obtained. This activity takes place from December 2019 to February 2020.

\subsection{Participants}

The research sample was 5 lecturers consisting of 3 women and 2 men in the age range 32-40 years. The sample selection uses a purposive sampling technique. Samples selected with criteria that fit the research are lecturers with their knowledge of education for at least 4 years at the Trunojoyo University Primary School Teacher Education Study Program as the main interview source who registers for an environmental education course.

\subsection{Instrument}

The instrument used by researchers in the form of structured interview questions sheets given to lecturers supporting environmental education courses. There are 3 main themes that are the focus of researchers in interviews, namely, planning, implementation, evaluation in applying the outdoor learning model. Each of the main themes was developed into a more detailed description of the question to get various sources of information about each theme.

The planning stage was developed into 3 areas, namely curriculum, potential, and planning. The curriculum was further developed into 15 questions based on the identity of the course, the description of the course, and the instructional analysis design of the course. In the potential section, it is developed into 20 questions based on the potential of the outdoor learning model being implemented as well as the potential need for the use of the outdoor learning model in environmental education courses. In the planning section, it was developed into 8 questions based on tools, study materials, and location plans for the implementation of the outdoor learning model. In the implementation phase, the researcher developed the questions into 15 questions based on technical questions and implementation controls. The evaluation phase of the researcher developed into 10 questions based on visibility, effectiveness, and efficiency.

Researchers need 2 weeks to conduct an interview. The length of time required is related to arranging a time with the source of the interview and finding related documents needed by the researcher to complete the interview information.

\subsection{Procedure}

Qualitative data analysis was carried out by researchers through several processes ranging from collecting interview results to describing the results. After the researcher prepares all the instruments needed, then the researcher validates the interview instrument in advance to the expert. Next, the researchers submitted an official permit for research from the campus of Yogyakarta State University addressed to the University of Trunojoyo Madura. Subsequently, a research permit was given to the University of Trunojoyo Madura to be followed up in the Primary School Teacher Education study program. The Chair of the Study Program appoints 5 lecturers by the criteria determined by the researcher. Researchers and lecturers communicate with each other after obtaining approval from the study program coordinator. Next, the researcher conveys what the interview questions will be so that the source can prepare all the supporting things needed to complete each interview submitted by the researcher. Researchers and sources conduct interviews with the agreed time. All data collected is then processed and analyzed by researchers to reach conclusions.

\subsection{Data Analysis}

The researcher collected interview data by noting what was said by the source. Researchers are also assisted by using a voice recorder to facilitate rediscovering what has not been recorded by researchers. The recorder results are then transcribed verbatim to be analyzed. Data from the interviews have been collected and then sorted. The researcher sorts out which data matches the theme and which does not match. Next, the researcher groups the data sections according to the order of the question themes. At this stage, similar statements from several sources are to be grouped together and reduced to find the main meaning of each question description that has been submitted. Furthermore, researchers describe the results of data that are obtained qualitatively.

\section{Results}

\subsection{Analyzing Curriculum Structure}

Interesting things that were obtained by researchers when in the preparation stage questions in applying the outdoor learning model were in the curriculum analysis section used. For example their response is:

"Before determining the use of the outdoor learning model in subjects, we analyze the curriculum, especially in the courses that we will teach. This course is very appropriate to apply the outdoor learning model with a variety of considerations both the proportion of subjects 50\% theory and 50\% practice and learning outcomes of this course lead students to do outdoor activities. " [S3]

Identity of environmental education courses, PSD 443 subject code, Number of two credits, Requirements for following courses are not available, this course is taken in Semester 5, nature of courses is mandatory for students in semester 5, Proportion of 50\% theory, 50\% practice. 
Graduates Competency Standards (SKL) 1) Disseminate innovative ideas to develop and improve the quality of education in primary schools; 2) Upholding the value of humanity in carrying out duties based on religion, morals, and ethics; 3) Contribute to improving the quality of life in a society, nation, state and the advancement of civilization based on Pancasila; 4) Cooperate and have social sensitivity and care for the community and the environment; 5) Demonstrate adaptive, critical, and selective attitudes towards the development of science and technology.

Course Learning Achievement (CPMK), namely students are expected to have an environmentally friendly attitude based on adaptability and criticism towards the development of science and technology and actively participate in finding solutions to various environmental problems around them. The CPMK is broken down into 8 parts, namely 1) Students are able to disseminate innovative ideas in creating a healthy environment in schools through understanding human relationships with the environment; 2) Students make alternative energy sources that are environmentally friendly based on science and technology for the Madurese community through understanding energy sources and needs in human life and its relation to environmental sustainability in an effort to improve the quality of community life; 3) Students are able to work together and have social sensitivity and care for the community and the environment based on an understanding of population, energy, water, land, air; 4) Students are able to contribute in improving the quality of society based on the analysis and understanding of students about ecological disturbances due to natural factors such as: Erupting Mountains and Earthquakes, and due to human behavior such as: Forest Fires, Pollution and Floods; 5) Students are able to disseminate innovative ideas in understanding sustainable development and environmental ethics to develop and improve the quality of education in elementary schools; 6) Students are able to show adaptive, critical and selective attitudes towards the development of science and technology in waste management; 7) Students are able to disseminate innovative ideas to develop and improve the quality of education in elementary schools and the UTM environment about nature conservation; 8) Students are able to contribute in improving the quality of community life through efforts to increase environmental awareness.

\subsection{Study the Potential and Needs of Courses}

In the stage before the implementation of the outdoor learning model, the lecturer sorts out the potential and needs of the course. For example their response is:

"We try to prepare everything well and mature before applying this model. The object that will be used as student learning, the right location, safe, not far from the university, and easy to control its implementation. " [S1]
"Prepare everything well and well before the implementation, planning, and evaluation planning used." [S5]

The object in the application of the outdoor learning model of environmental education courses is the environment of UPTD Elementary Schools and Communities in the Bangkalan Regency. The location of the object in the application of the outdoor learning model is in accordance with the learning outcomes of the course. The availability of locations for the application of outdoor learning models in environmental education courses is more than sufficient for the application of outdoor learning. Determination of the location of application may be in the community or in elementary schools. Students are free to choose the location of the application of outdoor learning while they are still in the Bangkalan district.

The issues raised as affordable study material by students are that students are expected to have an environmentally friendly attitude based on adaptability and criticism towards the development of science and technology and actively participate in finding solutions to various environmental problems around them. Supporting study materials in this course is the relationship between humans and the environment; Energy sources and needs in human life and their relation to environmental sustainability; Population, energy, water, land, air; Ecological disturbances due to natural factors such as Mount Eruption and Earthquakes, and due to human behavior such as Forest Fires, Pollution and Flooding; Sustainable development and environmental ethics; Waste management; Nature conservation; and increasing environmental awareness.

The location of the application of the outdoor learning model in the environmental education course is not far from the student learning center (campus of the University of Trunojoyo Madura) so that it does not interfere with other brands. The technique of determining the location of the learning implementation process is divided into 3 namely classes in the first meeting when the lecturer gives a briefing, submission of a product design plan by students and an assessment of product results; Media consultation in the form of Learning Management System (Schoology, Youtube, Whatsapp) as well as face to face as a form of group consultation outside of learning hours; The field is a location for students to study problems, observe and apply products. The location limit is determined by the lecturer, namely the UPTD SD and the community in the Bangkalan district.

The location of the application is by the learning achievements of environmental education courses, namely students are expected to have an environmentally friendly attitude based on adaptability and criticism towards the development of science and technology and actively participate in finding solutions to various environmental problems around them. The schedule for the implementation of the outdoor learning model is conducted 
during lecture hours and outside lecture hours (between Monday outside the lecture schedule and Saturday and Sunday) so that the schedule does not interfere with other lectures. Students use technology for the consultation process of various activities during the outdoor learning process, the form and process of permission for implementation in outdoor learning. Students as a group determine the theme, look for sources of literacy, determine the subject matter taken, design preliminary instruments to look for problems in the field. Furthermore, students conduct consultation and delivery of instruments to the lecturer regarding planned outdoor activities. Then students submit a letter of introduction for observation and implementation of outdoor learning to the faculty service department. If the implementation is at school, students apply for permission to the education office and the Regional Coordinator where the implementation of outdoor learning. Furthermore, students apply for permission to the UPTD Elementary School in the direction of bringing a permit and introduction from the campus, if the implementation is in the scope of the community, the application for a permit to the sub-district office and related village office. Furthermore, students apply for permission to go to the designated area by bringing a permit and introduction from the university.

Security in implementing the outdoor learning model can be controlled through supporting technological devices. The science and technology media as a control in the form of Learning Management System (Schoology, Youtube, Whatsapp) and face to face in the form of group consultations outside of learning hours. The form of guidance through the form of Learning Management System (Schoology, Youtube, Whatsapp) and face to face to face as a form of group consultation outside of learning hours. The need for information sources as learning material is the scope of Elementary School UPTD and the community environment in Bangkalan district. This source of information supports students in higher-order thinking skills. Technology and information are needed to control the process of outdoor learning, considering that lecturers cannot reach all locations used by students as outdoor learning. The forms of technology that are utilized in the learning process include the Learning Management System (Schoology, Youtube, Whatsapp).

Lecturers form groups according to the theme raised by dividing into 8 groups. Each group discusses the theme raised. Guidance in the outdoor learning process is very much needed considering that the activity requires guidance from the lecturer and further direction to fit the planned objectives. The form of guidance planned in the process of outdoor learning through the Learning Management System (Schoology, Youtube, Whatsapp) media as well as face to face as a form of group consultation outside of learning hours. Form of output reporting planned by the lecturer to obtain data that is used as a form of evaluation, namely 1) Product design; 2)
Documentation of activities during the outdoor learning process in the form of photos and videos; 3) Final report on outdoor learning activities.

\subsection{Planning Instruments}

Lecturers prepare all the needs of both the Syllabus, semester learning plan (RPS), learning planning (PP), Instructional Analysis Design (RAI), and course manuals. For example their response is:

"We prepare the learning tools first, starting from the preparation of the syllabus to the course manuals." [S2]

"Our preparation includes providing a syllabus, semester learning plans, learning planning, Instructional Analysis Design, and guidebooks." [S4]

The location of the implementation of the outdoor learning model in the environmental education course is not far from the student learning center (Trunojoyo Madura University campus) so that it does not interfere with other brands. The technical determination of the location of the learning implementation process is Class, in the first meeting when the lecturer gives a briefing, delivery of a product design plan by students and an assessment of product results; Consultation media, in the form of Learning Management System (Schoology, Youtube, Whatsapp) as well as face to face as a form of group consultation outside of learning hours; Field, is the location of students doing study problems, observations and applying products. The location limit is determined by the lecturer, namely the UPTD SD and the community in the Bangkalan district.

\subsection{Implementation}

At the implementation stage, the lecturer always controls well every week, utilizing various media that have been prepared and agreed upon, namely Schoology and Whatsapp as communication outside the lecture schedule. For example their response is:

"Everything that has been prepared for 16 weeks starts from the first week of the college contract, and the delivery of what is needed until the sixteenth week of the final report submission. All processes are always controlled and there is an evaluation when in the field " [S3]

"... in the process of implementing communication, it is always intertwined through WhatsApp and Schoology to facilitate our control in observing the ongoing learning." [S4]

The implementation of the learning process is valid for 16 weeks. The first meeting discusses the lecture contract, delivers the syllabus, and divides groups. In the second and third week, each group prepares all instruments according to the theme obtained for preparation to the field and 
making a permit for the implementation of outdoor learning. In the fourth week, students look for information through a study of potential needs and problems in the field related to the themes that have been shared previously. In the fifth and sixth week, students presented the results of potential needs and problems in the field and planned products to be made. The seventh and eighth week is the delivery of product design results to be applied to the field. At the ninth to twelfth meeting students apply the application of products in the field and observe developments. The thirteenth to the fifteenth meeting of the results of field activities, the fifteenth meeting of the final report making; the sixteenth meeting was the submission of the results of the final report and evaluation.

\subsection{Evaluation}

There are 3 evaluation categories used, namely visibility, effectiveness, and efficiency. For example their response is:

"We use the implementation documentation of both photos and videos uploaded on YouTube for evaluation of visibility. We also value skills and attitude assessments to measure the effectiveness of the application of the model. We use the questionnaire sheet to determine the efficiency of the model's implementation. " [S2]

As a form of evaluation in the form of documentation attached to the observation sheet at each stage summarized in the portfolio, and supported by video. We also evaluate attitudes and knowledge. We gave the questionnaire sheet to find out how efficient the implementation of this model was. " [S5]

Evaluations include Visibility obtained through observation sheets, video documentation of the implementation of activities, and portfolios; Evaluation of measured effectiveness in the form of attitudes, knowledge, and skills; Efficiency evaluation is obtained through a questionnaire sheet.

The results of various interviews conducted by researchers there are some interesting findings to be presented in this study. 4 sources said that students get many benefits from outdoor learning, namely encouragement to develop emotionally, behaviorally, and intellectually to develop optimally. 1 source conveyed the application of the outdoor learning model to encourage the creation of self-confidence, independence, creativity, responsibility in making decisions, and skills in solving problems that can develop very well. 5 sources agreed that the outdoor learning model was greatly enjoyed by lecturers and students; increasing enthusiasm in learning to obtain information was very high. This model involves all elements of both the school and the community in supporting the implementation of the outdoor learning model. This form of active communication exists during the outdoor learning process. This achievement is inseparable from good management. In the management of the outdoor learning model, there are 5 phases, all of which are interrelated with one another. 1) Analyzing curriculum structure; 2) Study the potential and needs of courses; 3) planning; 4) implementation; 5) evaluation. Then it can be illustrated in the following chart.

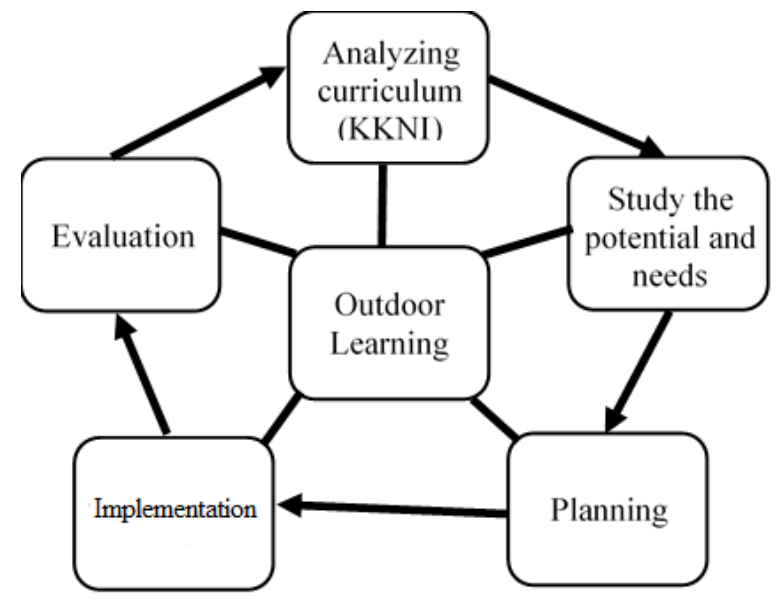

Figure 1. Chart of the management of outdoor learning models

\section{Discussion and Conclusions}

The performance of primary school teacher education study programs increases with the application of the outdoor learning model, increased behavior, attitude, and attendance when students are involved in the school and community environment. So many are directly involved in contributing to the community. Students learn firsthand experience in searching, processing information, and communicating with school residents and the community. The application of the outdoor learning model reduces the depression of students and lecturers because the learning model is very fun, increased physical activity through learning outside the classroom (Lester \& Maudsley, 2006; Wells \& Evans, 2003).

The outdoor learning model provides exceptional benefits for students, lecturers, and universities. Students can develop from various aspects both cognitive, affective, and psychomotor, lecturers can understand the various characters of students so they can help develop optimally. The university can be present and become closer to the community both as a source of information and various other contributions relevant to the field of science.

The descriptions of the 5 phases of outdoor learning model management are: (1) Analyzing the curriculum structure of the KKNI S1 Elementary School Teacher Education Program. (instrument). The environmental education course is one of the compulsory subjects of the Primary School Teacher Education study program. The weight of this course is 2 credits taken in semester 5 . The 
proportion of environmental education courses is 50\% theory and 50\% practice. Graduates Competency Standards (SKL) direct students to conduct outdoor lecture activities that are reduced to Learning Outcomes (CPMK) and sub-CPMK.

(2) Study the potential and needs of environmental education courses, the potential for the availability of supporting components in the form of objects in the application of the outdoor learning model, namely the UPTD of Elementary Schools and Communities in Bangkalan. Potential issues raised as study materials are affordable by students. The potential of the learning location is not far from the student learning center (Universitas Trunojoyo Madura) so that it does not interfere with other brands. The potential implementation of the outdoor learning model does not interfere with other lecture schedules. The security potential in implementing the outdoor learning model can be controlled and there is guidance from the lecturer as a manager. The need for information sources as learning material is the scope of Elementary School UPTD and the community environment in Bangkalan district.

(3) Planning in preparing learning tools in the form of syllabus, semester learning plans (RPS) and learning planning (PP), planning of study material and developing guidelines, and location planning to support outdoor learning and licensing models.

(4) Implementation in the form of control of the implementation process. Technical implementation starts with determining the location to support the outdoor learning model, licensing from the campus, community, and schools. The location of the application of the outdoor learning model in the environmental education course is not far from the student learning center (campus of the University of Trunojoyo Madura) so that it does not interfere with other brands. The technical determination of the location of the learning implementation process is divided into 3 namely 1) Classes in the first meeting when the lecturer gives directions, delivery of the product design plan by students as well as an assessment of product results; 2) Consultation media in the form of Learning Management System (Schoology, Youtube, Whatsapp) and face to face as a form of group consultation outside of learning hours; 3 ) The field is a location for students to study problems, observe and apply products. The location limit is determined by the lecturer, namely UPTD SD and the community in the Bangkalan district. Technical licensing in the implementation of outdoor learning in environmental education courses are divided into 5 stages: 1) Students as a group determine the theme, look for sources of literacy, determine the subject matter taken, design preliminary instruments to look for problems in the field; 2) Students carry out consultations and deliver instruments to lecturers regarding plans for outdoor activities; 3) Students submit a letter introducing permission for observation and implementation of outdoor learning to the faculty service department; 4) If the implementation is at school, students apply for permission to the education office and the Regional Coordinator where outdoor learning is implemented. Furthermore, students apply for permission to the UPTD Elementary School in the direction of carrying a permit and introduction from the campus; 5) If the implementation is in the scope of the community, the application for a permit to the sub-district office and the relevant village office. Furthermore, students apply for permission to the intended area by bringing a permit and introduction from the campus.

(5) Evaluations that can be done in the application of the outdoor learning model in environmental education courses are 3 namely Visibility evaluation in the form of observation sheets of videos and other supporting documents, evaluation of effectiveness (assessment of attitudes, knowledge, skills), and evaluation of efficiency

The conclusion from this study is that outdoor learning models have various positive impacts on their application. The outdoor learning model will be implemented well if it is accompanied by good management. There are 5 phases of managing outdoor learning models, all of which are interrelated with one another, namely analyzing curriculum structure, study the potential and needs of courses, planning, implementing, evaluating.

\section{Finding}

An interesting finding in this study is that outdoor learning models still require face-to-face class, but more time for activities outside the classroom. Activities in the class are in the form of initial coordination, delivery of product designs, and delivery of results. The management of the outdoor learning model needs to be tried in other subjects.

\section{Acknowledgments}

We are very grateful to experts for their appropriate and constructive suggestions to improve this template and to Indonesia Endowment Fund for Education.

\section{REFERENCES}

[1] American Institutes for research. (2005). Effect of outdoor education programs for children in California. Sacramento: the California department of education. Retrieved from http://benefitshub.ca/entry/effects-of-outdoor-education-pro grams-for-children-in-california/

[2] Baker, M., Waliczek, T., \& Zajicek, J. (2015). The Effect of School Gardening Activities on Visual-Motor Integration of Pre-School and Kindergarten Students. Journal of Therapeutic Horticulture, 25(2), 3-14. DOI: 
https://www.jstor.org/stable/248652644.

[3] Brodin, J. (2009). Inclusion through access to outdoor education: Learning in Motion (LIM). Journal of adventure education and outdoor learning, 9(2), 99-113. DOI: 10.1080/14729670903004340.

[4] Brodin, J., \& Lindstrand, P. (2006). Inclusion of children in outdoor education. : Learning in Motion. Stockholm: Inst. för barn och ungdomsvetenskap. Retrieved from http://urn.kb.se/resolve?urn=urn:nbn:se:su:diva-25994.

[5] Cuvo, A. J., May, M. E., \& Post, T. P. (2001). Effects of living room, Snozelen room, and outdoor activities on stereotypic behaviour and engagement by adults with profound mental retardation. Research in Developmental Disabilities, 22(3), 183-204. DOI: 10.1016/s0891-4222(01)00067-1.

[6] Dahlgren, L.-O., \& Szczepanski, A. (2005). Outdoor Education : literary education and sensory experience : an attempt at defining the identity of outdoor education. Beijing Company Ltd Beijing China. Retrieved from http://urn.kb.se/resolve?urn=urn:nbn:se:liu:diva-69324.

[7] Doctoroff, S. (2001). Adapting the physical environment to meet the needs of 'all' young children for play. Early Childhood Education Journal, 29(2), 105-109. DOI: 10.1023/A:1012524929004.

[8] Dyment, J. E., Bell, A. C. (2008). Grounds for movement: green school grounds as sites for promoting physical activity. Health Education Research, 23(6), 952-962. DOI: https://doi.org/10.1093/her/cym059.

[9] Eriksson-Dobrovich, I. (2007). (Ed.). Learning outdoors. Handbook for adults with mental disabilities. Learning in motion. Uppsala: Studiefrämjandet. Retrieved from https://www.buv.su.se/polopoly_fs/1.48830.1320917351!/T KH_43.pdf

[10] Holman, T., Goldenbe, M., McAvoy, L., \& Rynders, J. (2003). Outcomes-Consequences - Values of an Integrated Wilderness Adventure Program. Journal of Experiential Education, 25(3), 353-353. DOI: https://doi.org/10.1177/105382590302500318

[11] Johnson, P., \& Ivie, P. (2003). Guide for self-appraisal and certification of resident outdoor science school programs. (4th ed). Costa Mesa, CA: Orange country department of education, California outdoor school administrators. Retrieved from

https://www.sdcoe.net/student-services/outdoored/Docume nts/ab1330-chapter-contents.pdf

[12] Kuo, M., Taylor, A. F. (2004). A potential natural treatment for attention-deficit/hyperactivity disorder: evidence from a national study. American Journal of public health, 94(9), 1580-1586. DOI: 10.2105/AJPH.94.9.1580.

[13] Lester, S., \& Maudsley, M. (2006). Play, naturally: A review of children's natural play. Children's play council. Retrieved April 16, 2020, Retrieved from
http://www.playday.org.uk/PDF/play-naturally-a-review-of -childrens- natural\%20play.pdf.

[14] Magnussson, M. (2006). Inclusion of young persons in outdoor education. Learning in motion. Report 44, Stockholm institute of education, Stockholm. Retrieved from

http://www.buv.su.se/polopoly_fs/1.75639.1328875839!/m enu/standard/file/TKH_44.pdf

[15] Ministry of Education. (2007). Permendiknas tentang standar proses. Jakarta: Ministry of Education.

[16] Morris, J. and Zidenberg-Cherr, S. (2002) Garden-enhanced nutrition curriculum improves fourth-grade school children's knowledge of nutrition and preference for vegetables. Journal of the American Dietetic Association, 10, 91-93. DOI:http://dx.doi.org/10.1016/S0002-8223(02)9002 7-1.

[17] Neill, J. T., Marsh, H. W., \& Richards, G. E. (2003). The life effectiveness questionnaire development and psychometrics. Sydney university of western sydney. Retrieved from https://studylib.net/doc/18761590/the-life-effectiveness-que stionnaire

[18] Rickinson, M., Dillon, J., Teamey, K., Morris, M., Choi, M. Y., Sanders, D., \& Benefield, P. (2004). A Review of Research on Outdoor Learning. London: National foundation for educational research and king's college london. Retrieved from

https://www.academia.edu/288162/A_Review_of_Research _on_Outdoor_Learning.

[19] Setyawan, A., Aznam, N., Paidi, P., \& Citrawati, T. (2020). Influence of the use of technology through problem based learning and Inkuiri models are leading to scientific communication students class VII. Journal of Technology and Science Education, 10(2), 190-198. doi:http://dx.doi.org/10.3926/jotse.962

[20] Spencer, A. (2003). Playground of dreams, parks and recreation, 38(4). Retrieved from https://www.buv.su.se/polopoly_fs/1.48830.1320917351!/T KH_43.pdf

[21] Todd, Teri \& Reid, Greg. (2006). Increasing Physical Activity in Individuals With Autism. Focus on Autism and Other Developmental Disabilities - FOCUS AUTISM DEV DISABIL. 21(3). 167-176. DOI: $10.1177 / 10883576060210030501$.

[22] Wells, N.M., \& Evans, G.W. (2003). Nearby nature: A buffer of life stress among rural children. Environment and Behavior, 35(3), 311-330. DOI: 10.1177/001391650325144 5.

[23] Westberg, A. (2007). Den upproriska skötsamheten. Att vara ung och scout [The rebellious aspect of being well-behaved: To be young and scout] (Doctoral dissertation, Stockholm Institute of Education, Stockholm). Retrieved from https://www.diva-portal.org/smash/get/diva2:197712/FULL TEXT01.pdf 